\title{
Effect of Microwave Oven Drying on Production of Quality Dry Flowers of Roses
}

\author{
Gitam Sharma $^{1}$, S.V.S. Chaudhary ${ }^{1}$, Y.C. Gupta ${ }^{1}$, S.R. Dhiman ${ }^{1}$, \\ R.K. Dogra ${ }^{2}$ and R.K. Gupta ${ }^{3}$ \\ ${ }^{1}$ Department of Floriculture and Landscape Architecture, ${ }^{2}$ Department of Fruit Science, \\ ${ }^{3}$ Department of Basic Sciences, Dr YS Parmar University of Horticulture and Forestry \\ Nauni, Solan 173230 Himachal Pradesh, India \\ *Corresponding author
}

\section{Keywords}

Value addition, Dry flower, Dry roses,

Silica gel,

Microwave oven

Article Info

Accepted:

04 January 2019

Available Online:

10 February 2019
The study was carried out at the experimental farm of the Department of Floriculture and Landscape Architecture, Dr YS Parmar University of Horticulture and Forestry, Nauni, Solan. The data was taken for four flushes, that is, Flush I (November, 2017), Flush II (April, 2018), Flush III (June, 2018) and Flush IV (August, 2018). The cultivars selected for the experiment were Avalanche, Confetti, Corvette, First Red, Gavanna, Gold Strike, Hollywood, Nobelesse, Peach Avalanche, Sweet Avalanche, Taj Mahal and Tineke. After giving different drying treatments, dried flowers were scored on quality parameters i.e. flower colour, texture, brittleness and shape retention. The results of the study suggested that Taj Mahal can be used as a suitable cultivar for drying in Microwave oven during November (Flush I) and April (Flush II) flushes and Corvette during June (Flush III) and August (Flush IV) flushes.

\section{Introduction}

Rose occupies premier position among cut flowers in domestic as well as international markets. It is top ranking cut flower in the global flower trade with an annual turnover of 731 million Euros (Royal FloraHolland Facts and Figures, 2017). According to the estimates of National Horticulture Board (NHB, 2017), total production of cut flowers in India during 2015-16 was 593 thousand MT of which 301.95 thousand MT was of rose with an area of 29.41 thousand hectare.
Major rose Producing States/Districts in India are West Bengal, Karnataka, Gujarat, Chhattisgarh and Maharashtra. Fresh rose flowers though exquisite in their beauty are highly perishable and delicate in nature and cannot retain their beauty and fresh look for a long time in spite of using best chemicals for enhancing vase life. In this context rose flowers can be dried, preserved and processed to retain its beauty as well as everlasting value. The dry flower industry in India is about fifty years old and was introduced by the British. India stands fourth in dry flower 
exports worldwide. Potpourris being the major segment of drying flower industry valuing at Rs. 55 crores in India alone (Nirmala et al., 2008). In recent floriculture trade, the export of dry flowers from India during 2013-2014 was Rs. 363.3 crores (Periban et al., 2014). Indian export of flowers is composed of $71 \%$ dry flowers exported mainly to USA, Japan, Australia, Russia and Europe (De et al., 2016). As rose is one of the top ranking cut flowers in the international flower trade, dry cut flowers of roses are the most expensive and exquisite of all dried flowers traded in the international market (Barnett and Moore, 1999). Keeping in view the above facts, the present study was planned to find out the suitability of different cultivars of rose to be used as dry flower.

\section{Materials and Methods}

The study was carried out at the experimental farm of the Department of Floriculture and Landscape Architecture, Dr YS Parmar University of Horticulture and Forestry, Nauni, Solan. The data was taken for four flushes, that is, Flush I (November, 2017), Flush II (April, 2018), Flush III (June, 2018) and Flush IV (August, 2018). The experimental farm is located $1276 \mathrm{~m}$ above mean sea level at the latitude of $32^{\circ} 51^{\prime} 0^{\prime \prime} \mathrm{N}$ and longitude of $77^{\circ} 11^{\prime} 30^{\prime \prime} \mathrm{E}$. The experimental material consisted of twelve Hybrid Tea (H.T.) Rose varieties obtained from KSG Sons, Bangalore. The cultivars selected for the experiment were Avalanche, Confetti, Corvette, First Red, Gavanna, Gold Strike, Hollywood, Nobelesse, Peach Avalanche, Sweet Avalanche, Taj Mahal and Tineke (Plate 1). Healthy, disease free and uniform flower stem were harvested at half bloom stage (half bloom stage referred to the stage wherein $50 \%$ of the petals were open) (Safeena et al., 2006) in the afternoon when the moisture over the flowers dried and immediately after harvesting, they were put in water. They were then brought to the laboratory to give various treatments. The leaves present on each cut stem were removed before using them for drying. Plastic containers were selected for drying. They were filled evenly with the silica gel upto 4 inches of height. Depressions were made to insert the selected cut flowers into the medium. After inserting the flowers, the media was poured gently for uniform covering of the petals without deforming the petals. The media was evenly distributed so as to equalize the pressure on all sides of the flower. After inserting the flowers in the media, they were placed in the Microwave oven for the specified exposure durations i.e., 2 minutes, 2.5 minutes and 3 minutes. The containers were removed after the treatment and were kept as such for 48 hours without removing the flowers from the media. After drying, the embedded flowers were taken out carefully by tilting the containers. The flowers were rolled down and were collected. They were tapped by holding it from the stalk to remove the excess desiccant material. Petals were also gently brushed with soft camel hair brush to remove the desiccant completely so that the original colour of the dried flower could be seen. After giving different drying treatments, dried flowers were scored on following quality parameters i.e. flower colour, texture, brittleness and shape retention. A scale was developed and scores were given based on 5 points for each parameter as per the score card given in Table 1. Statistical analysis was carried out using Completely Randomized Design (Factorial).

\section{Results and Discussion}

\section{Quality parameters during flush I (November, 2017) (Plate 2)}

Scoring of dried cultivars is very important to assess their quality, therefore a score card was developed and cultivars were scored accordingly as presented in Table 2 . 
During Flush I, maximum score (16.84) was alloted to Nobelesse cultivar of rose which was found to be statistically at par with Confetti (15.77), Corvette (13.92), First Red (14.09), Gavanna (16.20), Gold Strike (14.73) and Taj Mahal (16.33). Whereas, minimum score (7.58) for quality parameters was alloted to Hollywood which was found to be statistically at par with Tineke (10.62).

Among exposure times, maximum score (14.65) was given to cultivars dried at 2 minutes exposure time which was found to be statistically at par with cultivars dried at 2.5 minutes exposure time. However, minimum score (12.55) was obtained by cultivars dried at 3 minutes exposure time.

Interaction of cultivars and exposure time was found to be non significant.

Quality parameters during flush II (April, 2018) (Plate 3)

During Flush II, maximum score (16.49) among different cultivars was observed in Taj Mahal which was found to be statistically at par with Confetti (16.25), Gavanna (15.27) and Nobelesse (16.05). Whereas, minimum score (9.22) was obtained by Hollywood which was found to be statistically at par with Avalanche (9.66), Gold Strike (11.63), Peach Avalanche (9.65), Sweet Avalanche (9.94) and Tineke (10.74) (Table 3).

Among exposure times, maximum score (13.76) was observed in cultivars dried at 2 minutes exposure time which was found to be statistically at par with those dried at 2.5 minutes exposure time. However, minimum score (11.68) for quality parameters was observed in 3 minutes exposure time.

Interaction of cultivars and exposure time showed that maximum score (18.37) was obtained by Nobelesse cultivar when dried at
3 minutes exposure time which was found to be statistically at par with Confetti (17.07), Corvette (15.44), First Red (15.83), Gavanna (15.43), Nobelesse (15.07) and Taj Mahal (17.00) dried at 2 minutes exposure time, Confetti (15.51), Corvette (16.17), First Red (15.43), Gavanna (14.33), Nobelesse (14.70) and Taj Mahal (15.77) dried at 2.5 minutes exposure time and Confetti (16.17), Gavanna (16.03) and Taj Mahal (16.71) dried at 3 minutes exposure time.

However, minimum score (4.71) was obtained by Peach Avalanche dried at 3 minutes exposure time which was found to be statistically at par with Hollywood (8.45) dried at 2 minutes exposure time, Avalanche (6.43), Corvette (8.37), Sweet Avalanche (7.23) and Tineke (8.43) dried at 3 minutes exposure time.

Interaction between cultivars and different time levels in microwave oven for quality parameters was found to be significant in the study by Safeena and Patil (2013) where overall acceptability was high for flowers of cv. 'Lambada' dried for 2.5 minutes in the microwave oven. This study confirms our finding too.

\section{Quality parameters during flush III (June,} 2018) (Plate 4)

Maximum score (15.86) during Flush III was observed in First Red which was found to be statistically at par with Confetti (14.19) and Corvette (14.64). However minimum score (9.40) was observed in Gavanna which was found to be statistically at par with Peach Avalanche (10.17) (Table 4).

Exposure times were found to be statistically non significant for different cultivars of rose during Flush III. Interaction of cultivars and exposure time was also found to be non significant. 
Quality parameters during flush IV (August, 2018) (Plate 5)

During Flush IV, maximum score (15.51) was obtained by Corvette which was found to statistically at par with First Red (14.50), whereas, minimum score (7.65) was observed in Gavanna which was found to be statistically at par with Peach Avalanche (8.12) (Table 5).

Among exposure times, maximum score (13.20) was observed for cultivars dried at 2 minutes exposure time and minimum (10.64) for cultivars dried at 3 minutes exposure time.

Interaction of cultivars and exposure time was found to be non significant.

\section{Pooled effect of flushes on quality parameters (Plate 6)}

Pooled data of all the flushes in Table 6 showed that in general, Taj Mahal scored maximum score (15.61) with respect to quality parameters which was found to be statistically at par with Confetti (15.57), Corvette (15.07), First Red (15.03) and Nobelesse (14.43). However, minimum score (10.79) for quality parameters was observed in Hollywood which was found to be statistically at par with Avalanche (11.81), Peach Avalanche (11.09) and Sweet Avalanche (11.57).

In general, among the flushes, maximum score (13.70) was observed in Flush I and minimum (11.90) in Flush IV which was found to be statistically at par with Flush III.

Interaction of cultivars and flushes show that maximum score (16.84) was observed in Nobelesse cultivar of rose during Flush I which was found to be statistically at par with Confetti (15.77), Gavanna (16.20), Gold Strike (14.73) and Taj Mahal (16.33) during
Flush I, Confetti (16.25), Gavanna (15.27), Nobelesse (16.05) and Taj Mahal (16.49) during Flush II, Corvette (14.64) and First Red (15.86) during Flush III and Corvette (15.51) and First Red (14.50) during Flush IV. However, minimum score (7.58) was observed in Hollywood during Flush I which was found to be statistically at par with Avalanche (9.66), Hollywood (9.22), Peach Avalanche (9.65) and Sweet Avalanche (9.94) during Flush II, Gavanna (9.40) during Flush III and Gavanna (7.65) and Peach Avalanche (8.12) during Flush IV.

Safeena and Patil (2013) reported significant difference due to different time levels, in which power output level for 2.5 minutes scored the highest points for colour, appearance and texture in rose cultivars. The flowers dried for 3 minutes scored the least for colour and for appearance thereby indicating failure to retain the original appearance after drying. According to them, among different time levels, subjecting the flowers to power output level for 2.5 minutes was found to be the best for drying of Dutch roses. Treating the flowers at this power output level was best with respect to colour, appearance and texture. Upon subjecting to longer duration of drying (3 minutes), the texture and colour retainment was poor. These results are in conformity with our results where drying at 2 minutes in microwave oven obtained maximum score and drying at higher time, i.e., 3 minutes resulted in minimum score. Increase in the temperature might have been the cause for poor colour.

Dhatt et al., (2007) dried rose buds in microwave oven for 3,4 and 5 minutes, respectively, and found that rose buds dried for 4 min exhibited good colour and good shape retention. Biswas and Dhua (2010) performed an experiment on microwave oven drying of cut Carnation varieties viz., Kristina and Cano. These were harvested at fully 
opened stage and then subjected to drying treatments in microwave oven (1200 watt) after embedding them in silica gel (desiccant) for 2 to 4 minutes.

The quality of dried flowers deteriorated more with increase in the drying duration and the lowest drying duration of 2 minutes showed the best results in both varieties with respect to appearance, colour, shape and sizes of dried flower as compared to drying duration of 3 or 4 minutes which is true for our study also.

Among the four different cultivars evaluated by Safeena and Patil (2013), dry flowers of 'Lambada' scored maximum points with respect to retention of colour, appearance and texture whereas least score of points for colour, appearance and texture was recorded in 'Ravel'.

Table.1 Score card for different quality parameters of dried flowers

\begin{tabular}{|c|c|c|c|c|c|c|c|}
\hline \multicolumn{2}{|l|}{ Colour } & \multicolumn{2}{|l|}{ Texture } & \multicolumn{2}{|c|}{ Brittleness } & \multicolumn{2}{|c|}{ Shape retention } \\
\hline Excellent & 5 & Smooth & 5 & Intact & 5 & Excellent & 5 \\
\hline $\begin{array}{l}\text { Very } \\
\text { Good }\end{array}$ & 4 & Medium & 3 & $\begin{array}{l}\text { Slightly } \\
\text { brittle }\end{array}$ & 3 & $\begin{array}{l}\text { Very } \\
\text { Good }\end{array}$ & 4 \\
\hline Good & 3 & Rough & 1 & Brittle & 1 & Good & 3 \\
\hline Poor & 2 & & & & & Poor & 2 \\
\hline Very Poor & 1 & & & & & Very Poor & 1 \\
\hline
\end{tabular}

Table.2 Effect of exposure time (E) on quality parameters of rose cultivars dried in microwave oven during Flush I (November, 2017) (score out of 20)

\begin{tabular}{|c|c|c|c|c|}
\hline $\begin{array}{ll}\text { Exposure time } \\
\text { Cultivars }\end{array}$ & 2 mins & $2.5 \mathrm{mins}$ & 3 mins & Mean \\
\hline Avalanche & 15.81 & 11.10 & 14.17 & 13.69 \\
\hline Confetti & 15.10 & 17.77 & 14.43 & 15.77 \\
\hline Corvette & 13.87 & 15.10 & 12.80 & 13.92 \\
\hline First Red & 17.10 & 12.80 & 12.37 & 14.09 \\
\hline Gavanna & 18.07 & 17.40 & 13.13 & 16.20 \\
\hline Gold Strike & 13.80 & 17.33 & 13.07 & 14.73 \\
\hline Hollywood & 8.39 & 7.15 & 7.18 & 7.58 \\
\hline Nobelesse & 17.43 & 15.70 & 17.40 & 16.84 \\
\hline Peach Avalanche & 16.83 & 12.87 & 10.85 & 13.52 \\
\hline Sweet Avalanche & 13.10 & 13.07 & 7.08 & 11.08 \\
\hline Taj Mahal & 17.48 & 13.43 & 18.07 & 16.33 \\
\hline Tineke & 8.77 & 13.07 & 10.03 & 10.62 \\
\hline Mean & 14.65 & 13.90 & 12.55 & \\
\hline \multicolumn{5}{|c|}{$\begin{array}{l}\mathrm{CD}_{0.05} \\
\text { Cultivars: } 3.07 \\
\text { Exposure time: } 1.53 \\
\text { Cultivars X Exposure time: NS }\end{array}$} \\
\hline
\end{tabular}


Table.3 Effect of exposure time (E) on quality parameters of rose cultivars dried in microwave oven during Flush II (April, 2018) (score out of 20)

\begin{tabular}{|c|c|c|c|c|}
\hline $\begin{array}{ll} & \text { Exposure time } \\
\text { Cultivars } & \end{array}$ & 2 mins & 2.5 mins & 3 mins & Mean \\
\hline Avalanche & 12.47 & 10.08 & 6.43 & 9.66 \\
\hline Confetti & 17.07 & 15.51 & 16.17 & 16.25 \\
\hline Corvette & 15.44 & 16.17 & 8.37 & 13.33 \\
\hline First Red & 15.83 & 15.43 & 9.77 & 13.68 \\
\hline Gavanna & 15.43 & 14.33 & 16.03 & 15.27 \\
\hline Gold Strike & 11.03 & 11.09 & 12.77 & 11.63 \\
\hline Hollywood & 8.45 & 9.80 & 9.40 & 9.22 \\
\hline Nobelesse & 15.07 & 14.70 & 18.37 & 16.05 \\
\hline Peach Avalanche & 13.74 & 4.71 & 10.50 & 9.65 \\
\hline Sweet Avalanche & 10.20 & 12.37 & 7.23 & 9.94 \\
\hline Taj Mahal & 17.00 & 15.77 & 16.71 & 16.49 \\
\hline Tineke & 13.40 & 10.40 & 8.43 & 10.74 \\
\hline Mean & 13.76 & 12.53 & 11.68 & \\
\hline
\end{tabular}

Table.4 Effect of exposure time (E) on quality parameters of rose cultivars dried in microwave oven during Flush III (June, 2018) (score out of 20)

\begin{tabular}{|c|c|c|c|c|}
\hline $\begin{array}{ll} & \text { Exposure time } \\
\text { Cultivars } & \end{array}$ & 2 mins & 2.5 mins & 3 mins & Mean \\
\hline Avalanche & 12.78 & 11.40 & 11.35 & 11.84 \\
\hline Confetti & 16.44 & 13.77 & 12.37 & 14.19 \\
\hline Corvette & 16.40 & 15.44 & 12.07 & 14.64 \\
\hline First Red & 16.77 & 15.80 & 15.00 & 15.86 \\
\hline Gavanna & 10.73 & 9.04 & 8.43 & 9.40 \\
\hline Gold Strike & 12.71 & 12.37 & 10.10 & 11.73 \\
\hline Hollywood & 13.14 & 12.04 & 11.51 & 12.23 \\
\hline Nobelesse & 12.70 & 10.77 & 9.71 & 11.06 \\
\hline Peach Avalanche & 10.67 & 10.11 & 9.73 & 10.17 \\
\hline Sweet Avalanche & 12.77 & 11.04 & 10.77 & 11.53 \\
\hline Taj Mahal & 13.10 & 12.08 & 11.33 & 12.17 \\
\hline Tineke & 13.13 & 13.03 & 10.77 & 12.31 \\
\hline Mean & 13.53 & 12.32 & 11.18 & \\
\hline \multicolumn{5}{|c|}{$\begin{array}{l}\mathrm{CD}_{0.05} \\
\text { Cultivars: } 1.81 \\
\text { Exposure time: NS } \\
\text { Cultivars X Exposure time: NS }\end{array}$} \\
\hline
\end{tabular}


Table.5 Effect of exposure time (E) on quality parameters of rose cultivars dried in microwave oven during Flush IV (August, 2018) (score out of 20)

\begin{tabular}{|l|l|l|l|l|}
\hline \multicolumn{1}{|c|}{ Exposure time } & $\mathbf{2}$ mins & $\mathbf{2 . 5}$ mins & $\mathbf{3}$ mins & Mean \\
\hline Avalanche & 12.40 & 11.87 & & \\
\hline Confetti & 15.51 & 12.52 & 9.18 & $\mathbf{1 1 . 1 5}$ \\
\hline Corvette & 16.17 & 15.23 & 15.47 & $\mathbf{1 3 . 1 7}$ \\
\hline First Red & 15.07 & 14.67 & 13.77 & $\mathbf{1 5 . 5 1}$ \\
\hline Gavanna & 8.73 & 7.77 & 6.44 & $\mathbf{1 4 . 5 0}$ \\
\hline Gold Strike & 13.88 & 11.28 & 10.50 & $\mathbf{7 . 6 5}$ \\
\hline Hollywood & 13.50 & 11.13 & 9.10 & $\mathbf{1 1 . 2 4}$ \\
\hline Nobelesse & 11.43 & 11.10 & 9.80 & $\mathbf{1 0 . 7 8}$ \\
\hline $\begin{array}{l}\text { Peach Avalanche } \\
\text { Sweet Avalanche }\end{array}$ & 8.40 & 8.14 & 7.83 & $\mathbf{8 . 1 2}$ \\
\hline Taj Mahal & 14.14 & 13.21 & 10.48 & $\mathbf{1 2 . 6 1}$ \\
\hline Tineke & 15.07 & 12.85 & 12.47 & $\mathbf{1 3 . 4 6}$ \\
\hline $\begin{array}{l}\text { Mean } \\
\text { CD } \\
\text { Cultivars: } \mathbf{2 . 0 0} \\
\text { Exposure time: } \mathbf{1 . 0 1}\end{array}$ & 14.10 & 12.53 & 11.53 & $\mathbf{1 2 . 7 2}$ \\
Cultivars X Exposure time: & $\mathbf{1 3 . 2 0}$ & $\mathbf{1 1 . 8 6}$ & $\mathbf{1 0 . 6 4}$ & \\
\hline
\end{tabular}

Table.6 Pooled effect of different flowering flushes on quality parameters of rose cultivars dried in microwave oven (score out of 20)

\begin{tabular}{|l|l|l|l|l|l|}
\hline $\begin{array}{c}\text { Exposure time } \\
\text { Cultivars }\end{array}$ & $\begin{array}{c}\text { Flush I } \\
\text { (November, } \\
\mathbf{2 0 1 7} \text { ) }\end{array}$ & $\begin{array}{c}\text { Flush II } \\
\text { (April, 2018) }\end{array}$ & $\begin{array}{c}\text { Flush III } \\
\text { (June, 2018) }\end{array}$ & $\begin{array}{c}\text { Flush IV } \\
\text { (August, } \\
\mathbf{2 0 1 8} \text { ) }\end{array}$ & Pooled Mean \\
\hline Avalanche & 13.69 & 9.66 & 11.84 & 11.15 & $\mathbf{1 1 . 8 1}$ \\
\hline Confetti & 15.77 & 16.25 & 14.19 & 13.17 & $\mathbf{1 5 . 5 7}$ \\
\hline Corvette & 13.92 & 13.33 & 14.64 & 15.51 & $\mathbf{1 5 . 0 7}$ \\
\hline First Red & 14.09 & 13.68 & 15.86 & 14.50 & $\mathbf{1 5 . 0 3}$ \\
\hline Gavanna & 16.20 & 15.27 & 9.40 & 7.65 & $\mathbf{1 2 . 8 2}$ \\
\hline Gold Strike & 14.73 & 11.63 & 11.73 & 11.89 & $\mathbf{1 3 . 2 5}$ \\
\hline Hollywood & 7.58 & 9.22 & 12.23 & 11.24 & $\mathbf{1 0 . 7 9}$ \\
\hline Nobelesse & 16.84 & 16.05 & 11.06 & 10.78 & $\mathbf{1 4 . 4 3}$ \\
\hline Peach Avalanche & 13.52 & 9.65 & 10.17 & 8.12 & $\mathbf{1 1 . 0 9}$ \\
\hline Sweet Avalanche & 11.08 & 9.94 & 11.53 & 12.61 & $\mathbf{1 1 . 5 7}$ \\
\hline Taj Mahal & 16.33 & 16.49 & 12.17 & 13.46 & $\mathbf{1 5 . 6 1}$ \\
\hline Tineke & 10.62 & 10.74 & 12.31 & 12.72 & $\mathbf{1 2 . 3 2}$ \\
\hline $\begin{array}{l}\text { Mean } \\
\text { CD } \\
\text { Cultivars: 1.19 }\end{array}$ & $\mathbf{1 3 . 7 0}$ & $\mathbf{1 2 . 6 6}$ & $\mathbf{1 2 . 2 6}$ & $\mathbf{1 1 . 9 0}$ & \\
\hline $\begin{array}{l}\text { Exposure time: } \mathbf{0 . 6 9} \\
\text { Cultivars X Exposure time: } \mathbf{2 . 3 8}\end{array}$ & & & & \\
\hline
\end{tabular}


All the floral characteristics like colour, appearance and texture were best in the orange coloured cv. 'Lambada' followed by yellow coloured cv. 'Skyline'. This result is in confirmation with the findings of Datillo (2001) who opined that, brighter the flower longer the colour last. The bright orange roses such as Prominent, Fragrant cloud, Impatient, Marina, Tropicana, Carrot top and Holy Toledo will dry glorious orange. Yellow flowers retain their colour well, but white ones may become dull gray-brown after drying. Dark red flowers and others with deep hues may become even darker during drying. The differences in flower colour may be due to varietal character. These studies confirm findings in our study where red, orange, pink and yellow coloured cultivars obtained maximum score and white coloured ones minimum.

The variation among the cultivars with respect to shape retention, brittleness and texture may be owed to the characteristic feature of the cultivar as observed by Safeena and Patil (2013). Acharyya et al., (2013) reported rose cultivar 'Gold Medal' scored a maximum of $71.8 \%$, while 'Minu Parle' scored $66.1 \%$ in microwave-silica gel drying. Such a difference in scoring of drying rose cultivars was also reported by Sohn et al., (2003).

Flowers dried during Flush I (November, 2017) scored maximum due to better appearance of flowers particularly more anthocyanin content (Table 6) as compared to other flushes. This might be due to favourable environmental conditions prevailing during Flush I.

In conclusion, the results of the present study suggests that Taj Mahal can be used as a suitable cultivar for drying in Microwave oven during November (Flush I) and April (Flush II) flushes and Corvette during June
(Flush III) and August (Flush IV) flushes. The dehydrated flowers retain their original shape, size and colours and can be used in value addition. This diversification in floriculture in terms of floral craft can become the basis of cottage industry both for domestic and International Markets. Development of awareness among the youth and rural women about dehydration of flowers and preparation of value added dried flowers are very much essential at this juncture.

\section{References}

Barnett T, Moore F. The ultimate book of fresh and dried flowers. Lorenz Books, USA. 1999, 3-4.

Biswas, C., and Dhua, R. S. 2010. Microwave oven drying of cut carnation. J. Orn. Hort. 13(1): 45-49.

Datillo, S. (2001). Preserving roses by drying. http://www.ars.org/drying.html.

De, L.C., Rai, W., Sumanthapa, and Singh, D.R. 2016. Drying technologies of commercial flowers- an overview. Int. J. Res. Appl. Nat. Social Sci. 4(3): 111120.

Dhatt, K.K., Singh, Kushal and Kumar, Ramesh (2007). Studies on methods of dehydration of rose buds. J. Orna. Hort., 10(4): 264-267.

Horticulture at a glance. 2017. National Horticulture Board Database (NHB). www.nhb.gov.in

Nirmala A, Chandrasekhar R, Padma M, Raj Kumar M. 2008. Standardization of drying techniques of carnation (Dianthus caryophyllus). Journal of Ornamental Horticulture. 11:168-172.

Acharyya P, Biswas S, Saha S and Chakraborty L. 2013. Studies on Methods of Dehydration of Rose Buds 'Gold Medal' and 'Minu Parle' Acta Hort. 970, ISHS 2013. 293-298

Periban S, Majumder J, Singh B, Rai T, Kumar R. Dried flowers: a new 
paradigm in Floriculture, 2014. Safeena, S.A., Patil, V.S. and Naik. B. Hemla http:/www.Krishisewa.com/cms/articles/ pht/394-driedflowere.html.

Royal FloraHolland Facts and Figures. 2016. https://www.royalfloraholland.com

Safeena, S.A., and Patil, V.S. 2013. Effect of hot air oven and microwave oven drying on production of quality dry flowers of Dutch roses. J. Agric. Sci. 5: 179-189. (2006a). Standardization of stage of harvest for better quality of dry flowers of rose. J. Orna. Hort., 9(3): 224-226.

Sohn Kwan, Hwa, Jin, Kwon Hye and Young, Kim Eui (2003). Effects of drying methods on shape and colour of Rosa hybrida. Korean J. Horti. Sci. \& Technol., 21(2): 136- 140.

\section{How to cite this article:}

Gitam Sharma, S.V.S. Chaudhary, Y.C. Gupta, S.R. Dhiman, R.K. Dogra and Gupta, R.K. 2019. Effect of Microwave Oven Drying on Production of Quality Dry Flowers of Roses. Int.J.Curr.Microbiol.App.Sci. 8(02): 300-308. doi: https://doi.org/10.20546/ijcmas.2019.802.035 